\title{
Relationship of Family Support to Diabetes Mellitus Type 2 Self-Management Behavior in Sumbang Health Center 1, Banyumas District
}

\author{
$1^{\text {st }}$ Maria Paulina Irma Susanti \\ Health Faculty, University of Harapan \\ Bangsa, R Patah St. No 100, Ledug, \\ Kembaran, Purwokerto Timur, Banyumas, Jawa Tengah \\ mariapaulinai@uhb.ac.id
}

\begin{abstract}
Self-control is important for people with Diabetes Mellitus, this is obtained if you get support from your family. Reminding each other or controlling management is diabetics. Whether we realize it or not, when someone experiences diabetes mellitus they will experience difficult times. They must begin to improve themselves, begin to control their eating patterns and activities. It definitely needs help from people around, especially families, by telling the condition of diabetes mellitus in the closest person, it will help in diet control and treatment programs. Goal. This research is to find out the relationship between family support and behavior of management sef of persons with type 2 Diabetes Mellitus in Puskesmas 1 Sumbang, Banyumas Regency.
\end{abstract}

Method. This type of research is correlational research with a cross sectional approach. Sampling uses a saturated sampling technique. 81 respondents. The data collection instrument used is a questionnaire.

The results of statistical tests using Spearmans Rank showed that there was a relationship between family support and self management behavior with a p value of 0.001 Conclusion. There is a relationship between family support and selfmanagement in people with Type II Diabetes Mellitus in Sumbang 1 Public Health Center, Banyumas Regency.

Keywords: family support, self-management, diabetes mellitus

\section{INTRODUCTION}

Diabetes mellitus (DM) or diabetes, including degenerative diseases. Changes in human lifestyles in the community are one of the reasons DM disease affects more

\author{
$2^{\text {nd }}$ Adiratna Sekar Siwi \\ Health Faculty, University of Harapan \\ Bangsa, R Patah St. No 100, Ledug, \\ Kembaran, Purwokerto Timur, Banyumas, Jawa Tengah, \\ adiratnasekarsiwi@uhb.ac.id
}

and more people. Various facilities for life and various types of foods that contain high sugar and fat content, have become a scapegoat for the increasing number of people with DM in Indonesia and other countries in the world.

The population in this study were all people with Diabete Mellitus in Puskesmas 1 Sumbang Banyumas Regency as many as 81 people. The sampling technique is total sampling (taking all respondents) ie 81 respondents.se interventions was done in groups (for physical exercise) to further improve motivation and social relations among nurses in the hospital. Then the intervention supervised by experts (Physical Therapist) to be more effective. The other emphasis is the intervention is more practical if it is based on technology (eHealth). Based on the limitations of this systematic review, going forward, stronger methodological studies are needed to define the most effective and sustainable interventions for each type of work-related disease.

\section{METHODOLOGY}

This study uses a quantitative approach with cross sectional design with the aim of identifying whether there is a relationship between the dependent variable and the independent variable in one measurement using a questionnaire measuring instrument. The purpose of this study was to analyze the relationship between family support and self-management of people with DM Family is the most important part for everyone. Similarly, for people with diabetes mellitus. Whether we realize it or not, when someone has diabetes mellitus, they will have hard times. They must begin to improve themselves, begin to control their diet and activities. It is definitely in need of help from people around especially families, by telling the condition of diabetes mellitus to the closest people, it will help in diet control and treatment programs (Wardani, et al, 2014). Therefore, the family can remind or control the selfmanagement of diabetics. 
RESUlTS AND DisCUSSION

\section{Description of \KHLespondent【s characteristics}

\begin{tabular}{|l|l|l|l|}
\hline No & Variabel & $\mathrm{f}$ & $\%$ \\
\hline 1 & Job & & \\
& Housewife & 39 & 48,1 \\
& laborers & 26 & 32,1 \\
& Entrepreneur & 12 & 14,8 \\
& Retired & 4 & 4,9 \\
\hline 2 & Age & & \\
& $35-49$ & 10 & 12,3 \\
& $50-69$ tahun & 69 & 85,2 \\
& $>70$ tahun & 2 & 2,5 \\
\hline 3 & Sex & & \\
& Male & 24 & 29,6 \\
& Female & 57 & 70,4 \\
\hline 4 & Education & & \\
& Elementary & 58 & 71,6 \\
& Junior & 15 & 18,5 \\
& Senior & 8 & 9,9 \\
\hline 5 & Long suffered & 58 & 71,6 \\
& $1-5$ year & 23 & 28,4 \\
\hline & $>5$ year & \multicolumn{2}{|l}{} \\
\hline
\end{tabular}

Based on table 1 shows that the age of respondents is mostly in the age category 50-69 years as many as 69 respondents $(85.2 \%)$, the gender of the respondents is mostly female as many as 57 respondents (70.4\%), the last education of respondents is mostly elementary namely as many as 58 respondents $(71.6 \%)$, the majority of respondents' jobs were housewife as many as 39 respondents (48.1\%), and the length of time suffering from diabetes mellitus was mostly in the span of 1-5 years ie as many as 58 respondents $(48.1 \%)$.

2. Frequency Distribution of Respondents Based on Family Support

\begin{tabular}{lcc}
\hline Family Support & $\begin{array}{c}\text { Frekuensi } \\
\text { (f) }\end{array}$ & $\begin{array}{c}\text { Persentase } \\
(\mathbf{\%})\end{array}$ \\
\hline Weak & 1 & 1,2 \\
Moderate & 61 & 75,3 \\
Strong & 19 & 23,5 \\
\hline \multicolumn{1}{c}{ Total } & 81 & $\mathbf{1 0 0}$
\end{tabular}

Based on table 2 shows that family support for people with diabetes mellitus is mostly in the moderate category as many as 61 respondents $(75.3 \%)$, and a small proportion in the less category is as much as 1 respondent $(1.2 \%)$

3. Frequency Distribution of Respondents Based on Self-Management

\section{Self}

Management (\%)

\begin{tabular}{lcc}
\hline Weak & 1 & 1,2 \\
Moderate & 53 & 65,4 \\
Strong & 27 & 33,3 \\
\hline \multicolumn{1}{c}{ Total } & $\mathbf{8 1}$ & $\mathbf{1 0 0}$
\end{tabular}

Based on table 3 shows that Self-Management in people with diabetes mellitus in Puskesmas 1 Sumbang Banyumas Regency is highest in the medium category as many as 53 respondents $(65.4 \%)$ and a small portion in the less category as much as 1 respondents $(1.2 \%)$.

\section{Relationship of Family Support with Self Management}

\begin{tabular}{|c|c|c|c|c|c|c|c|c|c|}
\hline \multirow[t]{3}{*}{ Family Support } & \multicolumn{6}{|c|}{ Self Management } & \multirow{2}{*}{\multicolumn{2}{|c|}{ Total }} & \multirow{3}{*}{$\begin{array}{l}\mathrm{P} \\
\text { value } \\
0,001\end{array}$} \\
\hline & \multicolumn{2}{|c|}{ Weak } & \multicolumn{2}{|c|}{ Moderate } & \multicolumn{2}{|c|}{ Strong } & & & \\
\hline & $\mathrm{F}$ & $\%$ & $\mathrm{~F}$ & $\%$ & $\mathrm{~F}$ & $\%$ & $\mathrm{~F}$ & $\%$ & \\
\hline Weak & 0 & 0 & 0 & 0 & 1 & 1,3 & 1 & 1,3 & \\
\hline Moderate & 1 & 1,3 & 47 & 58 & 13 & 16 & 61 & 75,3 & \\
\hline Strong & 0 & 0 & 6 & 7,5 & 13 & 16 & 19 & 23,5 & \\
\hline Total & 1 & 1,3 & 53 & & 27 & & 81 & 100 & \\
\hline
\end{tabular}

Table 4 shows that the majority of respondents had moderate family support and 53 respondents (65.4\%) had moderate self-management. Based on the Spearman-rank test results obtained $p$ value is 0.001 , which means $p$ value $\leq \mathrm{a}(0.001 \leq 0.05)$ then Ho is rejected and $\mathrm{Ha}$ is accepted, it can be concluded that there is a relationship between family support and self- management. (75.3\%) or 61 respondents had moderate family.

\section{DISCUSSION}

1. Characteristics of respondents based on age, sex, last education, occupation, and duration of suffering

a) Age

Age of respondents mostly in the age range $50-69$ years as many as 69 respondents $(85.2 \%)$. This is in line with research conducted by Tamara, 2014 at Arifin Achmad Regional Hospital of Riau Province that of 46 respondents with diabetes mellitus, 21 of them were 45-55 years old. In accordance with research conducted by Ferawati, 
The results of this study indicate that people with diabetes mellitus have a level of selfmanagement that is less likely to get less family support. Conversely, people with diabetes mellitus with moderate levels of selfmanagement tend to get adequate family support. The results of the analysis note that there is a relationship between family support and self-management in people with Diabetes Mellitus Type II in Puskesmas 1 Sumbang Banyumas with a $\mathrm{p}$ value $=0,0001$.

\section{CONCLUSION}

The results of this study are in line with previous studies conducted by Tamara et al (2014) which showed that the incidence of type II DM is high in women due to a decrease in the hormone estrogen due to menopause. Research by Sari et al (2018) states that women constitute the most sex with a total of 44 respondents (71\%).

\section{c) Past Education}

Most of the respondents' last education was elementary, as many as 58 respondents $(71.6 \%)$. This is consistent with previous research conducted by Rahmawati (2016) states that the majority of respondent education is at the low education level of 21 respondents $(63.6 \%)$. Sari et al. (2018) stated that the majority of respondents had an elementary school education of 33 respondents (53.2\%). Education according to Notoatmodjo (2012) influences healthy behaviors, those behaviors that are related to one's efforts or activities to maintain and improve their health. Healthy behavior includes 3 aspects, namely prevention, health improvement, and nutritional behavior. If someone is getting higher education of course the level of awareness will be higher and will affect the prevention or treatment of hypertension.

d) Work

Most respondents' occupations were housewives with 39 respondents $(48.1 \%)$.

\section{e) Long suffer}

Based on table 4.1, it was found that the length of time suffering from diabetes mellitus was mostly respondents in the range of 1-5 years, as many as 58 respondents $(48.1 \%)$. This is in line with previous research conducted by Rahmawati (2016) which states that most of the longstanding respondents suffered from diabetes mellitus in the range of 1-5 years, as many as 24 respondents $(72.7 \%)$.

\section{Relationship of Family Support with SelfManagement of Type II Diabetes Mellitus in Puskesmas 1 Sumbang} Banyumas Regency

Based on table 4 it is known that the majority of respondents $(75.3 \%)$ or as many as 61 respondents have moderate family support and 53 respondents (65.4\%) have moderate selfmanagement. Whereas respondents who have less family support are 1 respondent $(1.3 \%)$ with less self-management as much as 1 respondent $(1.3 \%)$.
1. Most respondents who suffer from diabetes mellitus in the postbindu Pisangan Health Center work area have the following characteristics:
a) Women
b) More than $>45$ years old
c) Education of elementary school
d) Work as an IRT and with a long period of suffering $1-5$ years

2. Family support for people with diabetes mellitus is mostly in the moderate category as many as 61 respondents $(75.3 \%)$

3. Self-Management among people with diabetes mellitus in Puskesmas 1 Sumbang Banyumas Regency is highest in the medium category, which is 53 respondents $(65.4 \%)$

4. The majority of respondents $(75.3 \%)$ or 61 respondents had good family support and 53 respondents $(65.4 \%)$ had moderate selfmanagement. Based on the Spearman-rank test results obtained $\mathrm{p}$ value is 0.001 , which means $\mathrm{p}$ value $\leq \mathrm{a}(0.001 \leq 0.05)$ then $\mathrm{Ho}$ is rejected and $\mathrm{Ha}$ is accepted, it can be concluded that there is a relationship between family support and self-management

\section{REFERENCES}

[1] Ariani. Y, Sitorus. R, Gayatri. D. 2012. Hubungan Antara Motivasi dan Efikasi Diri Pasien Diabetes Melitus Tipe 2 dalam Asuhan Keperawatan Di RSUP. H. Adam Malik Medan. Tesis. Depok :

Fakultas Keperawatan, Universitas Indonesia. Diambil dari https://media.neliti.com/media/publications 108281-ID-motivasi-dan-efikasi-diripasiendiabete.pdf Diakses pada tanggal 2 Juni 2019

[2] Arikunto, S. 2010. Prosedur Penelitian : Suatu Pendekatan Praktik. Jakarta : Rineka Cipta

[3] Damayanti Santi. 2017. Efektivitas (Selfefficacy Enhancement Intervention Program (SEEIP)) Terhadap Efikasi Diri Manajemen Diabetes Mellitus Tipe 2. Diambil dari http://nursingjurnal.respati.ac.id/index.php/ 
JKRY/article/view/104 Diakses pada tanggal 2 Juni 2019

[4] Depkes. 2013. Profil Kesehatan Jawa Tengah Tahun 2013. Diambil dari

http://www.depkes.go.id/resources/downlo ad/profil/PROFIL_KES_PROVINSI_2013/13_Pro v_Jateng_2013.pdf Diakses pada tanggal $2-$ Juni 2019

[5] Friedman, Marylin M. 2010. Family Nursing : Research, Theory, \& Practice. Edisi 5. Jakarta : EGC

[6] Gita Pertiwi, N. 2015. Pengaruh Self-Efficacy Terhadap Hasil Belajar pada Siswa Kelas V Sekolah Dasar Daerah Binaan Iv Kecamatan Cilacap Selatan Kabupaten Cilacap. Diperoleh darihttp://lib.unnes.ac.id/21060/1/1401411500s.pdf Diakses pada tanggal 2 Juni 2019

[7] Hidayat, A.A. (2006). Pengantar Kebutuhan Dasar Manusia : Aplikasi Konsep dan Proses Keperawatan, Jilid 1. Jakarta : Salemba Medika.

[8] Howard, S. 2011. Glycosylated Hemoglobin; HbAlc. Diabetes care net.

[9] Kementrian Kesehatan RI. 2014. Infodatin Pusat Data dan Informasi Kementrian Kesehatan RI.

Diambil dari

http://www.depkes.go.id/resources/downlo ad/pusdatin/infodatin/infodatindiabetes.pdf Diakses pada tanggal 2 Juni 2019

[10] Kharismasanthi, P, A, D. 2015. Hubungan Dukungan Keluarga Dengan Efikasi Diri Pasien Diabetes Melitus Tipe 2 di Poliklinik Penyakit Dalam Rumah Sakit Tk.II dr. Soepraoen Malang. Tesis. Malang : Fakultas Kedokteran Universitas Brawijaya. Diambil dari http://repository.ub.ac.id/125113/ Diakses pada tanggal 2 Juni 2019

[11] Notoatmodjo, S. 2010. Metodologi Penelitian Kesehatan. Jakarta : Rineka Cipta.

[12] Nuraisya. F, Kusnanto. H, Rahayujati. T.B. 2017. Dukungan Keluarga dan Kualitas Hidup Pasien Diabetes Mellitus. Journal Of Community
Medicine and Public Health. Diambil dari https://media.neliti.com/media/publications /196160-ID-dukungan-keluarga-dankualitas-hiduppas.pdf Diakses pada tanggal 2 Juni 2019

[13] Nurhayani. Yani, 2016. Gambaran Efikasi Diri pada Pasien Diabetes Melitus Tipe II di RSUD Arjawinangun Kabupaten Cirebon. Diambil dari http://jurnal.akpermuh.ac.id/index.php/jam c/article/view/27/25 pada tanggal Diakses pada tanggal 2 Juni 2019

[14] PERKENI. 2011. Petunjuk Praktis Pengelolaan Diabetes Melitus Tipe 2. Jakarta : $\mathrm{PB}$

[15] Rahmawati. (2016) Pengaruh Program Diabetes Self-Management Education Terhadap Manajemen Diri Pada Penderita Diabetes Mellitus Tipe 2. https:// pdfs.semanticscholar. org/c486/da7 c9dfda68b9a3 616e6ea 74ec ff699 8932f.pdf diakses tanggal 26 juli 2019.

[16] Sari, Citra Windani Mambang dkk. (2018). Hubungan Self-Management dan SelfEfficacy Pada Pasien Diabetes Melitus di Kota Bandung. https://

ejournal.bsi.ac.id/ejurnal/index.php/jk/artic le/view/3694/2359 diakses tanggal 26 juli 2019

[17] Smeltzer \& Bare. 2013. Keperawatan MedikalBedah Brunner dan Suddart Edisi 3. Jakarta : EGC

[18] WHO. 2018. Media Centre World Health Organization Diambil dari https:/www.who.int/mediacentre/factsheet s/fs138/en/ Diakses pada tanggal 2 Juni 2019

[19] Yogasmoro, D. 2017. Hubungan Antara Dukungan Keluarga Dengan Efikasi Diri Pada Siswa SMP Menjelang Ujian Nasional (UN) di SMP Gunungjati 2 Purwokerto. Skripsi. Purwokerto : Fakultas Kesehatan, Sekolah Tinggi Ilmu Kesehatan Harapan Bangsa 